\title{
Eksistensi Pendidikan Islam Dalam Bingkai Regulasi Pendidikan Di Indonesia Pasca Kemerdekaan
}

\author{
Harmonedi \\ Universitas Islam Negeri (UIN) Imam Bonjol Padang \\ harmonedi@gmail.com \\ M. Zalnur \\ Universitas Islam Negeri UIN Imam Bonjol Padang \\ zalnur@gmail.com
}

\begin{abstract}
Islamic education existed in Indonesia along with Islam comed. The existence of Islamic education has a long history along with the history of the life journey of the Indonesian people. Islamic education faces a variety of dynamics along with political dynamics. Through this research, it will be revealed how the existence of Islamic education in the framework of education regulation in Indonesia: problems, solutions and strategies in its development. This research uses descriptive method with a library research approach, which is research conducted by reading various papers related to the issues being studied. Based on the research, it is found that education regulations in post-independence Indonesia always accommodate Islamic education, because Muslims are the majority comunity in Indonesia. The government's efforts to accommodate Islamic education were carried out gradually, and it was heavily influenced by political dynamics. This can be seen in several regulations issued by the government since the early independence period, orde baru, and pasca reformasi. The latest education regulations that accommodate Islamic education are Law Number 20 of 2003 about the National Education System and Law Number 18 of 2019 about pesantren. The existence of these two laws is an opportunity and at the same time a challenge for Islamic education, not only to overcome its own problems, but also to continue to develop itself and increase its role in nation building.
\end{abstract}

Keywords: Islamic Education, Regulation, Opportunities, challenge

Abstrak: Pendidikan Islam sudah eksis di Indonesia seiring dengan masuknya Islam. Eksistensi pendidikan Islam memiliki sejarah yang panjang seiring sejarah perjalanan hidup bangsa Indonesia. Pendidikan Islam menghadapi berbagai macam dinamika seiring dengan terjadinya dinamika politik. Melalui penelitian ini akan diungkap bagaimana eksistensi pendidikan Islam dalam bingkai regulasi pendidikan di Indonesia : problematika, solusi dan strategi dalam pengembangannya. Penelitian ini menggunakan Metode Deskriptif dengan pendekatan kepustakaan (library research), yaitu penelitian yang dilakukan dengan membaca berbagai karya tulis yang terkait dengan persoalan yang dikaji. Berdasarkan penelitian ditemukan bahwa regulasi pendidikan di Indonesia pasca kemerdekaan selalu mengakomodir pendidikan Islam, karena memang umat Islam merupakan kelompok mayoritas di Indonesia. Upaya pemerintah untuk mengakomodir pendidikan Islam dilakukan secara bertahap, dan itu sangat dipengaruhi oleh dinamika politik. Hal itu dapat

Belajea: Jurnal Pendidikan Islam Vol. 5, No 2, 2020; 309- 338

p-ISSN 2548-3390; e-ISSN 2548-3404, DOI:10.29240/belajea.v5i2.1331

http://journal.iaincurup.ac.id/indek.php/belajea 
dilihat pada beberapa regulasi yang diterbitkan pemerintah semenjak periode awal kemerdekaan, orde baru, dan pasca reformasi. Regulasi pendidikan terbaru yang mengakomodir pendidikan Islam adalah Undang-Undang Nomor 20 Tahun 2003 tentang Sistem Pendidikan Nasional dan Undang-Undang Nomor 18 Tahun 2019 tentang Pesantren. Keberadaan kedua undang-undang ini menjadi peluang dan sekaligus tantangan bagi pendidikan Islam, tidak hanya untuk mengatasi problematikanya sendiri, tetapi juga untuk terus mengembangkan diri dan meningkatkan kiprahnya dalam pembangunan bangsa.

Kata kunci: Pendidikan Islam, Regulasi, Peluang, Tantangan

\section{Pendahuluan}

Kajian tentang eksistensi pendidikan selalu menarik untuk dibahas, karena memang pendidikan merupakan kebutuhan yang sangat mendasar bagi manusia di negara manapun, tidak terkecuali di Indonesia. Setiap bangsa di seluruh dunia mempunyai perhatian khusus terhadap pendidikan. Perhatian itu dipastikan dapat ditemukan dalam konstitusi negaranya dan perundangundangan serta peraturan-peraturan yang mengikutinya bahwa negara berkewajiban untuk menyelenggarakan pendidikan bagi warganya. Pendidikan mempunyai hubungan integral dengan komponen-komponen dalam kehidupan berbangsa dan bernegara, seperti politik, ekonomi, sosial, budaya, pertahanan dan keamanan dan sebagainya. Faktor determinan membangun kehidupan yang lebih baik, termasuk kehidupan berbangsa adalah sumber daya manusia (SDM).

Kajian tentang eksistensi pendidikan Islam di Indonesia juga merupakan kajian yang menarik untuk dibahas. Karena kajian itu terlalu luas, maka dikerucutkan kepada eksistensi pendidikan Islam dalam bingkai regulasi pendidikan di Indonesia. Pendidikan Islam di Indonesia mempunyai latar belakang sejarah dan kebudayaan yang tiang pertamanya dipancangkan pada abad ke 8 M. Sampai kini pendidikan Islam di Indonesia telah berkembang dalam kurun waktu lebih dari 12 abad. Di sebagian besar wilayah negeri ini, kultur kehidupan masyarakatnya telah diwarnai oleh dampak positif pendidikan Islam. Oleh karena itu nilai-nilai Islami dalam intensitasnya berbeda-beda di berbagai wilayah Indonesia, telah menjiwai kehidupan masyarakat dan individu seperti nampak pada perilaku sosial yang mendorong terwujudnya kegiatan gotong royong (ukbuwah Islamiyah), sikap-sikap dan pandangan yang religius serta kepercayaan terhadap Tuhan Yang Maha Esa. ${ }^{1}$

${ }^{1}$ Sarno Hanipudin, Pendidikan Islam di Indonesia dari Masa ke Masa, Matan Journal of Islam and Muslim Society 1, 1 (2019), hlm: 2 - 5 
Pendidikan Islam terus bergerak secara dinamis seiring dengan terjadinya dinamika politik di Indonesia. Sekalipun pendidikan Islam memberikan andil besar terhadap kehidupan masyarakat dan individu masyarakat Indonesia, namun dalam realitasnya tentu menghadapi berbagai tantangan dan tantangan terutama ketika dihadapkan kepada realitas kehidupan masyarakat serta regulasi yang mengatur pendidikan nasional.

Melalui tulisan ini dikaji tentang eksistensi pendidikan Islam dalam bingkai regulasi pendidikan di Indonesia pasca kemerdekaan, yang meliputi : eksistensi pendidikan Islam pada masa penjajahan dan masa kemerdekaan, kedudukan pendidikan Islam dalam sistem pendidikan di Indonesia, kedudukan pesantren sebagai lembaga pendidikan Islam di Indonesia, problematika pendidikan Islam, solusi dan strategi dalam pengembangannya.

\section{Metodologi Penelitian}

Obyek penelitian ini adalah eksistensi pendidikan Islam dalam bingkai regulasi pendidikan di Indonesia pasca kemerdekaan. Penelitian difokuskan kepada regulasi yang dibuat pemerintah untuk mengatur pelaksanaan pendidikan Islam, serta problematika pendidikan Islam, solusi dan strategi dalam mengatasinya. Oleh sebab itu, penelitian ini menggunakan Metode Deskriptif dengan pendekatan (library research), yaitu penelitian yang dilakukan dengan membaca berbagai karya tulis yang terkait dengan persoalan yang dikaji, ${ }^{2}$ lalu menyajikanya seraca naratif.

Sumber data primer dalam penelitian ini adalah: (1) buku karya Haidar Putra Daulay, 2004, Pendidikan Islam dalam Sistem Pendidikan Nasional di Indonesia, Jakarta: Prenada Media, (2) buku karya Azyumardi Azra, 1999, Pendidikan Islam Tradisi dan Modernisasi Menuju Milenium Baru, Jakarta: Logos Wacana Ilmu, (3) buku karya Ramayulis, 2012, Sejarah Pendidikan Islam, Jakarta: Kalam Mulia, (4) buku karya Abdullah Idi dan Suharto Ito, 2006, Revitalisasi Pendidikan Islam, Yogyakarta : Tiara Wacana, (5) Undang-Undang Nomor 20 Tahun 2003 tentang Sistem Pendidikan Nasional, dan (6) Undang-Undang Nomor 18 Tahun 2019 tentang Pesantren.

Sedangkan sumber data sekunder adalah: (1) buku karya H.M Arifin, 1991, Pendidikan Islam dalam Arus Dinamika Masyarakat, Jakarta : Golden Terayon Press, (2) buku karya H.M Arifin, 1991, Kapita Selekta Pendidikan Islam dan Umum, Jakarta : Bumi Aksara, (3) buku karya Chairusdi, 1999, Sejarah Perjuangan dan Kiprah PERTI dalam Dunia Pendidikan Islam di Minangkabau, Padang: IAIN "IB" Press, (4) buku terbitan Departemen Agama RI, 1994, Panduan Kurikulum hlm 5

${ }^{2}$ Mestika Zed, Metode Penelitian Kepustakaan. (Jakarta : Yayasan Obor Indonesia, 2007), 
Madrasah Aliyab1994, Jakarta: Depag RI, 1994, (5) artikel yang ditulis oleh Suroyo, Berbagai Persoalan Pendidikan; Pendidikan Nasional dan Pendidikan Islam di Indonesia, Jurnal Pendidikan Islam, Kajian tentang Konsep Pendidikan Islam, Problem dan Prospeknya, Volume 1 Tahun 1991, Fakultas Tarbiyah IAIN, Yogyakarta, serta (6) Karya tulis lain yang relevan.

Langkah-langkah dalam penelitian ini adalah heuristik, kritik sumber, sintesis dan historiografi. Teknik pengumpulan datanya adalah: a) Editing, yaitu pemeriksaan terhadap data-data tentang eksistensi pendidikan Islam dalam bingkai regulasi pendidikan di Indonesia: problematika, solusi dan strategi dalam pengembangannnya, terutama dari segi kelengkapan, kejelasan makna dan koherensi makna antara yang satu dengan yang lainnya. b) Organizing, yakni menyusun data-data tentang eksistensi pendidikan Islam dalam bingkai regulasi pendidikan di Indonesia: problematika, solusi dan strategi dalam pengembangannnya. c) Penemuan hasil penelitian, yakni melakukan analisis lanjutan terhadap hasil penyusunan data dengan menggunakan kaidah-kaidah, teori dan metode yang telah ditentukan sehingga diperoleh kesimpulan tentang eksistensi pendidikan Islam dalam bingkai regulasi pendidikan di Indonesia: problematika, solusi dan strategi dalam pengembangannnya yang merupakan jawaban dari rumusan masalah yang telah ditetapkan. Analisis data dilakukan dengan menggunakan metode deskriptif analisis, yaitu mendeskripsikan dan menelaah data dengan maksud menemukan pokok permasalahan dan hubungannya di antara bagian-bagian untuk memperoleh pemahaman yang tepat dan menyeluruh tentang pokok bahasan. ${ }^{3}$

\section{Pembahasan}

Untuk melihat eksistensi pendidikan Islam di Indonesia pasca kemerdekaan, maka ada baiknya terlebih dahulu melihat eksistensinya pada masa penjajahan (Belanda dan Jepang). Sedangkan eksisitensinya pada masa pasca kemerdekaan perlu dilihat semenjak awal kemerdekaan hingga hari ini. Hal itu ditujukan agar objek bahasan ini beserta dinamikanya dapat dilihat secara komprehensif.

\section{Pendidikan Islam di Indonesia pada Masa Penjajahan}

Selama berabad-abad Islam diajarkan melalui jalur pendidikan informal dan non-formal. Jalur pendidikan informal adalah pendidikan yang dilakukan di rumah tangga. Sedangkan jalur pendidikan non-formal dilakukan di padepokan dan pondok pesantren,serta dakwah dengan berbagai model yang dilakukanoleh

\footnotetext{
${ }^{3}$ Sumardi Suryabrata, Metodologi Penelitian, (Jakarta: PT Raja Grafindo, 2006), hlm 40
} 
para ulama dengan pendekatan kultural edukatif. Cara itu dapat membawa perubahan sikap hidup individual dan sosial yang tinggi, serta kepekaan terhadap kemungkaran yang terjadi di lingkungannya.

Namun budaya yang mengandung nilai-nilai Islami itu dalam proses perkembangannya mulai mengalami gangguan dan ancaman dari kebudayaan asing yang dibawa oleh penjajah Belanda pada tahun $1596 \mathrm{M}$ (abad $16 \mathrm{M}$ ). Sebab penjajah Belanda datang ke Indonesia tidak hanya bertujuan merebut kekuasaan (glory) dan menguasai sumber daya alam (gold), tetapi juga membawa misi agama (gospel). Sedikit demi sedikit cakrawala budaya masyarakat dan pola pikirnya dipenetrasi oleh budaya dan pola pikir Eropa sehingga pada sisi-sisi konfigurasinya semakin lemah daya tangkalnya, dan semakin meluas ke arah episentrumnya. ${ }^{5}$

Bersamaan dengan munculnya sistem pendidikan klasikal yang diperkenalkan oleh oleh kaum penjajah, muncul pula di sana-sini model pendidikan formal/klasikal yang disebut madrasah. Model pendidikan madrasah itu makin kokoh mentradisi dalam masyarakat Islam di berbagai wilayah yang penduduknya mayoritas muslim. Dan setelah kembalinya beberapa ulama dari Mesir dan Saudi Arabia, ide-ide pembaharuan yang dicetuskan oleh cendekiawan muslim di Mesir dan Saudi Arabia, seperti Jamaluddin al-Afghani, Muhammad Abduh, Muhammad Ibnu Abdul Wahab, dan lain-lain, membuat model madrasah semakin dijadikan tumpuan bagi pelestarian dan modernisasi oleh umat Islam.

Pondok pesantren sebagai model pendidikan karakteristik Indonesia yang tradisional Islami tetap berkembang di samping madrasah, bahkan antara kedua model ini saling berdampingan sebagai saudara kembar dalam pengertian organisatoris dan keilmuan.

Sementara itu sekolah-sekolah umum yang minus pendidikan agama didirikan oleh Gubernemen (Pemerintah Belanda), sekolah-sekolah Islam partikulir yang plus agama Islam didirikan pula oleh beberapa organisasi mesyarakat. Sehingga terjadilah dua kubu yang berbeda pola pendidikannya. Di satu pihak pendidikan sekolah umum hanya berorientasi kepada duniawi yang etis, di lain pihak madrasah dan pondok pesantren berorientasi kepada ukhrawi yang populis. Pada akhirnya terjadilah kesenjangan dalam pola pendidikan yang semakin diperlebar oleh pemerintah Belanda, bahkan dijadikan pola pikir politik pecah belah (devide et impera). Masing-masing kubu saling mengejek satu sama lain

${ }^{4}$ Meirison Meirison et al., "نمط الدعوة في إندونيسيا وتحدياته," AL-'ABQARI: Journal of Islamic Social Sciences and Humanities 0, no. 0 (October 3, 2019), accessed October 31, 2019, http://abqarijournal.usim.edu.my/index.php/abqari/article/view/193.

${ }^{5}$ Ibid, hlm 88 
sehingga tanpa disadari terjadi dikotomi pendidikan dengan jurang pemisah yang amat dalam. ${ }^{6}$

Sekalipun Pemerintah Belanda memberikan ruang untuk berdirinya lembaga pendidikan Islam, namun pada masa itu tidak mudah bagi masyarakat pribumi untuk (rakyat Indonesia) untuk bergerak di bidang pendidikan Islam. Hal ini disebabkan Pemerintah Belanda sangat mengekang kebebasan umat Islam untuk bergerak di bidang itu. Pemerintah Belanda membuat berbagai kebijakan diskriminatif. Di satu sisi mereka membantu perkembangan sekolahsekolah gereja, namun di sisi lain mereka mempersulit dan menekan keberadaan sekolah-sekolah yang berbasis Islam.

Pada tahun 1819 M Gubernur Jenderal Van Der Capellen mengambil inisiatif merencanakan berdirinya sekolah dasar bagi penduduk pribumi agar dapat membantu Pemerintah Belanda. Dalam surat edarannya kepada para bupati tersebut sebagai berikut: "Dianggap penting untuk secepat mungkin mengadakan peraturan pemerintah yang menjamin meratanya kemampuan membaca dan menulis untuk penduduk pribumi agar mereka lebih mudah untuk dapat mentaati Undang-Undang dan Hukum Negara."

Agaknya kebijakan Pemerintah Belanda mempersempit ruang gerak pendidikan Islam lebih didasari oleh kekhawatiran terhadap bakal munculnya kader-kader nasionalis dan agamis yang dapat mengganggu eksistensi penjajahan Belanda di Indonesia. Oleh sebab itu Pemerintah Belanda terus melakukan tindakkan itu. Hal ini tercermin dari kebijakannya dengan membentuk badan khusus yang bernama Priesteraden pada tahun 1882 M. Badan ini bertugas mengawasi kehidupan beragama dan pendidikan Islam. Atas nasihat dari badan ini maka pada tahun 1905 M Pemerintah Belanda membuat peraturan yang dinamakan Ordonansi Guru Agama (Godsdienstoderwijs) yang isinya mewajibkan guru agama untuk meminta izin kepada Pemerintah Belanda dalam melakukan kegiatan mengajar dan operasional sekolah. ${ }^{8}$

Pada tahun 1925 M Pemerintah Belanda mengeluarkan peraturan yang lebih ketat lagi, yaitu tidak membolehkan semua orang memberikan pelajaran mengaji. Kemudian pada tahun 1932 M keluar pula peraturan yang dapat memberantas dan menutup madrasah dan sekolah yang tidak berizin, atau memberikan pelajaran yang tidak disukai oleh pemerintah. Peraturan itu disebut

${ }^{6}$ Meirison Meirison, "Kurds, Islam, and Secularism," Madania : Jurnal Kajian Keislaman 23, no. 1 (July 7, 2019), hlm: 47.

7Zuhairini, Sejarah Pendidikan Islam, (Jakarta : Bumi Aksara, 1997), hlm 148

${ }^{8}$ Chairusdi, Sejarah Perjuangan dan Kiprah PERTI dalam Dunia Pendidikan Islam di Minangkabau, (Padang: IAIN “IB” Press, 1999), hlm 113 
Ordonansi Sekolah Liar (Wilde School Ordonantie). Sementara itu untuk melindungi agama Kristen, dan untuk mencegah masuknya pelajaran agama ke sekolah umum pemerintah mengeluarkan peraturan yang disebut Netral Agama, yang isinya: pemerintah bersikap tidak memihak kepada salah satu agama sehingga sekolah pemerintah tidak mengajarkan pelajaran agama.'

Terjadi pro dan kontra di kalangan praktisi pendidikan Islam saat itu dalam merespon pemberlakuan ordonansi oleh Pemerintah Belanda. Di Jawa umumnya para kiyai mau menerima peraturan itu. Namun di daerah luar Jawa, seperti di Minangkabau para ulama sepakat untuk tidak mau memberlakukan Ordonansi karena mereka menilai peraturan itu hanyalah niat jahat Belanda untuk mengekang pendidikan Islam. Kesepakatan ulama ini diambil melalui rapat besar pada tanggal 18 Agustus 1928 M atas prakarsa Abdul Karim Amrullah. ${ }^{10}$

Setelah Belanda dikalahkan oleh Jepang di Indonesia tanggal 8 Maret 1945, maka sejak saat itu Indonesia dijajah oleh Jepang. Secara politis Jepang memiliki kepentingan besar terhadap umat Islam di Indonesia, sebab jumlah umat Islam yang mayoritas dapat dijadikan modal besar untuk menghadapi perang pasifik, perang Asia Timur Raya. Karena itu Jepang berulangkali menyampaikan maksudnya menghormati dan menghargai Islam. Jepang tidak begitu menghiraukan kepentingan agama, yang penting bagi mereka adalah bagaimana bisa memenangkan perang. Oleh sebab itu Jepang tidak mengusik eksistensi pendidikan Islam, malahan pemuka agama lebih diberikan keleluasaan dalam mengembangkan pendidikan Islam. ${ }^{11}$

Dalam kondisi seperti itu lembaga pendidikan Islam tetap muncul di Indonesia dan berperan sebagai penangkal terhadap nilai-nilai kultur Barat yang dibawa oleh penjajah. Walaupun pendidikan Islam didesak oleh nilai-nilai westernisasi melalui kekuasaan birokrasi dan politik kolonial, namun pendidikan Islam tetap berkembang di daerah pedesaan dan di kalangan masyarakat marjinal. Pendidikan Islam tetap menampilkan ciri khas wajahnya dalam perkembangan bangsa Indonesia sampai proklamasi kemerdekaan Indonesia.

Berkembangnya pendidikan Islam di masa penjajahan Jepang ditandai dengan beberapa indikator: (1) Munculnya madrasah awaliyah sampai pelosok desa. (2) Diajarkannya pelajaran budi pekerti di sekolah pemerintah. Hal ini memberi kesempatan bagi guru agama Islam untuk mengisinya dengan pelajaran agama. dan (3) Pemerintah Jepang mengizinkan berdirinya Sekolah Tinggi Islam

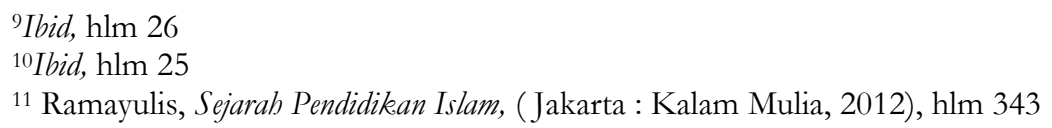


di Jakarta yang dipimpin oleh KH. Wahid Hasyim, Kahar Muzakkir, dan Bung Hatta. ${ }^{12}$

\section{Pendidikan Islam pada Masa Setelah Kemerdekaan}

Setelah kemerdekaan Indonesia pendidikan Islam memasuki babak baru. Berdasarkan pendekatan kultural sebagaimana disebutkan di atas, pendidikan Islam dalam berbagai model dan institusinya tetap mendapat kesempatan untuk berkembang oleh Pemerintah Republik Indonesia terutama dalam keikutsertaannya dalam membina akhlak bangsa yang berkepribadian Pancasila. Negara Kesatuan Republik Indonesia yang secara konstitusional ber Ketuhanan Yang Maha Esa, memberikan kebebasan beribadah bagi para pemeluk agama sesuai dengan kepercayaannya. Pasal 29 UUD 1945 dibangun atas landasan idil Pancasila yang merupakan kristalisasi dari esensi kehidupan kultural bangsa menghendaki agar watak sosialistik-religius rakyatnya tetap lestari dan diperkokoh melalui pendidikan agama termasuk pendidikan Islam.

Perkembangan pendidikan Islam setelah kemerdekaan Indonesia sangat terkait dengan peran Kementerian Agama yang resmi berdiri 3 Januari 1946. Lembaga ini secara inisiatif memperjuangkan politik pendidikan Islam di Indonesia. Secara lebih spesifik, usaha ini ditangani oleh suatu badan khusus yang mengurus masalah pendidikan agama. Penyelenggaraan pendidikan Islam mendapat perhatian serius dari pemerintah, baikdi sekolah negeri maupun swasta. Usaha untuk itu sudah dimulai dengan memberikan bantuan terhadap lembaga pendidikan Islam sebagaimana yang dianjurkan oleh Badan Pekerja Komite Nasional Pusat (BPKNP) tanggal 27 Desember 1945, yang menyebutkan bahwa madrasah dan pesantren pada hakekatnya adalah suatu alat dan sumber pendidikan dan pencerdasan rakyat jelata yang sudah berurat berakar dalam masyarakat Indonesia umumnya, hendaklah pula mendapat perhatian dan bantuan nyata berupa tuntutan dan bantuan dari pemerintah. ${ }^{13}$

Sebagai bentuk pengakuan dan perhatian pemerintah terhadap pendidikan Islam maka dilahirkan berbagai peraturan perundangan yang mengatur pendidikan Islam itu. Pada tahun 1950 madrasah sebagai lembaga penyelenggara pendidikan diakui oleh negara secara formal. Undang-undang nomor 4 tahun 1950 tentang Dasar-Dasar Pendidikan dan Pengajaran di sekolah pada pasal 10 disebutkan " Belajar di sekolah agama yang telah mendapat pengakuan Kementerian Agama, sudah dianggap memenuhi kewajiban belajar". Untuk mendapat pengakuan dari Kementerian Agama, madrasah harus

\footnotetext{
${ }^{12}$ Ibid, hlm 344

${ }^{13}$ Anton Timur Djailani, dalam Ramayulis, Ibid,hlm 347
} 
memberikan pelajaran agama sebagai mata pelajaran pokok paling sedikit enam jam seminggu secara teratur di samping mata pelajaran umum. ${ }^{14}$

Dalam dekade 1970-an madrasah terus dikembangkan untuk memperkuat keberadaannya, namun di periode awal tahun 1970-an justru kebijakan pemerintah terkesan berupaya mengisolasi madrasah dari bagian sistem pendidikan nasional. Hal ini terlihat dengan langkah yang ditempuh pemerintah dengan mengeluarkan Keputusan Presiden (Kepres) Nomor 34 tanggal 18 April Tahun 1972 tentang Tanggung Jawab Fungsional Pendidikan dan Latihan. Isi keputusan ini pada intinya mencakup tiga hal, yakni :

Menteri Pendidikan dan Kebudayaan bertugas dan bertanggung jawab atas pembinaan pendidikan umum dan kejuruan.

Menteri Tenaga Kerja bertugas dan bertanggung jawab atas pembinaan dan latihan keahlian dan kejuruan tenaga kerja akan pegawai negeri.

Ketua Lembaga Administrasi Negara bertugas dan bertanggung jawab atas pembinaan pendidikan dan latihan khusus untuk pegawai negeri. ${ }^{15}$

Selanjutnya Kepres Nomor 34 Tahun 1972 ini dipertegas oleh Inpres Nomor 15 Tahun 1974 yang mengatur operasionalnya. Dalam TAP MPRS Nomor XVII Tahun 1966 dijelaskan “ agama merupakan salah satu unsur mutlak dalam pencapaian tujuan nasional. Persoalan keagamaan dikelola oleh Departemen Agama, sedangkan madrasah dalam TAP MPRS Nomor 2 Tahun 1960 adalah lembaga pendidikan otonom di bawah pengawasan Menteri Agama". Dari ketentuan ini, Departemen Agama menyelenggarakan pendidikan madrasah tidak saja bersifat keagamaan dan umum, tetapi juga bersifat kejuruan. Dengan Kepres Nomor 34 Tahun 1972 dan Inpres Nomor 15 Tahn 1974, penyelenggaraan pedidikan umum dan kejuruan sepenuhnya berada di bawah tanggung jawab Mendikbud. Secara inplisit ketentuan ini mengharuskan diserahkannya penyelenggaraan pendidikan madrasah yang sudah menggunakan kurikulum nasional kepada Depdikbud. ${ }^{16}$

Seiring berjalannya waktu maka pada tahun 1975 pemerintah melalui Menteri Agama, Menteri Pendidikan dan Kebudayaan, dan Menteri Dalam Negeri mengeluarkan Surat Keputusan Bersama yang disebut SKB Tiga Menteri Nomor 6 Tahun 1975, No. 037 /U/ 1975 dan No. 36 Tahun 1975 tanggal 24 Maret 1975 tentang Peningkatan Mutu Pendidikan Madrasah. Keputusan bersama tersebut merupakan pelaksanaan dari Keputusan Presiden No.15

${ }^{14}$ Ibid, hlm 350
${ }^{15}$ Haidar Nawawi, dalam Samsul Nizar, Sejarah Pendidikan Islam, Jakarta : Kencana Prenada Media Group, 2009), hlm 362

${ }^{16}$ Ibid 
Tahun 1972 dan Instruksi Presiden No.15 Tahun 1974, sesuai dengan petunjuk presiden pada sidang kabinet terbatas tanggal 26 November 1974. SKB ini pada akhirnyamelahirkan kurikulum baru tahun 1976 untuk Madrasah Ibtidaiyah, Tsanawiyah dan Aliyah beserta jurusan-jurusannya (Syariah, IPS, Matematika, Bahasa, dan IPA). Sedangkan kedudukan pendidikan agama di sekolah umum tingkat dasar sampai dengan universitas negeri (yang diperkuat dengan TAP MPR, no. IV/1973, no.IV/1978 dan TAP.no. II/1983 tentang GBHN) direalisasikan dengan kurikulum 1984 (untuk SMA). Disamping madrasah sebagai sarana peningkatan penghayatan dan pengamalan ajaran Islam, semakin mapan dan istiqamah. ${ }^{17}$

SKB Tiga Menteri tahun 1975 diperkuat lagi dengan dikeluarkan pula SKB 2 Menteri, antara Menteri Pendidikan dan Kebudayaan dan Menteri Agama No. 0299/U/1984 (Dikbud) ; No. 045 Tahun 1984 (Agama) tentang Pengaturan Pembakuan Kurikulum Sekolah Umum dan Sekolah Madrasah yang isinya antara lain ; penyamaan mutu lulusan madrasah dan dapat melanjutkan ke sekolah-sekolah umum yang lebih tinggi. Menindaklanjuti SKB 2 Menteri Tahun 1984, lahirlah kurikulum 1984 untuk madrasah yang tertuang dalam Keputusan Menteri Agama Nomor 99 Tahun 1984 untuk Madrasah Ibtidaiyah, Nomor 100 Tahun 1984 untuk Madrasah Tsanawiyah, dan Nomor 101 Tahun 1984 untuk Madrasah Aliyah. ${ }^{18}$

Langkah-langkah strategis lainnya dalam rangka pengembangan madrasah dapat dilakukan setelah diberlakukannya UU Nomor 2 Tahun 1989 tentang Sistem Pendidikan Nasional (Sispenas). ${ }^{19}$ Sebagai pelaksanaan Undangundang tersebut di dalam Peraturan Pemerintah Nomor 28 Tahun 1990 tentang Pendidikan Dasar dalam Bab III Pasal 4 ayat (3) disebutkan bahwa : "Sekolah Dasar dan Sekolah Lanjutan Pertama yang berciri khas agama Islam yang diselenggarakan oleh Departemen Agama masing-masing disebut Madrasah Ibtidaiyah dan Madrasah Tsanawiyah". Di pihak lain dalam Keputusan Menteri Pendidikan dan Kebudayaan Nomor 0489/VU 1992 tentang Sekolah Menengah Umum dalam pasal 1 ayat (6) disebutkan bahwa :"Madrasah Aliyah adalah Sekolah Menengah Umum yang berciri khas agama Islam yang diselenggarakan oleh Departemen Agama".

Sehubungan dengan itu Madrasah Ibtidaiyah, Madrasah Tsanawiyah dan Madrasah Aliyah wajib memberikan bahan kajian minimal sama dengan SD, SLTP dan SMU, di samping bahan kajian lain yang diberikan pada Madrasah

\footnotetext{
${ }^{17}$ HM. Arifin, Loc.Cit

${ }^{18}$ Ramayulis, Ibid, hlm 358

${ }^{19}$ Undang-Undang Nomor 2 Tahun 1989 Tentang Sistem Pendidikan Nasional
} 
tersebut. Hal ini tertuang dalam pasal 26 Keputusan Mendikbud No. 0487/V/1992 dan pasal 22 ayat (6) No. 0489/U 11992. Madrasah mempunyai tugas yang sama dengan sekolah umum, yaitu memberikan kemampuan kepada peserta didik untuk mengembangkan kehidupan sebagai pribadi, anggota masyarakat, warga negara dan anggota umat manusia serta mempersiapkannya untuk mengikuti pendidikan yang lebih tinggi. Namun dalam aspek lain Madrasah tetap mempunyai ciri khas tersendiri. Sehubungan dengan hal ini dikeluarkanlah Surat Keputusan Menteri Agama Nomor 372 Tahun 1993 tentang Kurikulum Pendidikan Dasar Berciri Khas Agama Islam (terdiri dari Madrasah Ibtidaiyah dan Madrasah Tsanawiyah) dan Nomor 373 Tahun 1993 tentang Kurikulum Madrasah Aliyah. ${ }^{20}$

Selanjutnya pada Tahun 1993 dibuka Madrasah Aliyah Program Khusus (MAPK). Sebagai payung hukum berdirinya lembaga adalah Keputusan Menteri Agama Nomor 374 Tahun 1993. Dalam MAPK ini pendidikan agama memperoleh porsi porsentase yang lebih tinggi seperti tertuang dalam kurikulum MAPK Tahun 1993, yaitu $70 \%$ agama dan $30 \%$ umum. Perbandingan kurikulum MAPK ini pada hakekatnya dimaksudkan untuk mengembangkan program pembibitan calon-calon ulama sehingga pembukaan MAPK pada dasarnya adalah program intensifikasi pendidikan melalui sistem asrama dan mengembangkan kemahiran berbahasa Arab dan Inggris. ${ }^{21}$

Pada Tahun 2003 pendidikan Islam di Indonesia memasuki babak baru setelah terbitnya UU Nomor 20 Tahun 2003 tentang Sistem Pendidikan Nasional (Sisdiknas). Undang-undang ini banyak mengatur tentang kedudukan, fungsi, jalur, jenjang, jenis dan bentuk kelembagaan madrasah. Melalui undangundang ini diatur kedudukan pendidikan Islam sebagai mata pelajaran di lembaga pendidikan umum, serta kedudukan pendidikan Islam sebagai Sub Sistem Pendidikan Nasional.

Selanjutnya pada tanggal 15 Oktober 2019 terbitUU Nomor 18 Tahun 2019 tentang Pesantren. Undang-undang ini lebih banyak mengatur tentang kedudukan, fungsi, jalur, jenjang, jenis dan bentuk kelembagaan pesantren. Terbitnya UU Nomor 20 Tahun 2003 tentang Sisdiknas dan UU Nomor 18 Tahun 2019 tentang pesantren merupakan sejarah baru bagi eksistensi pendidikan Islam di Indonesia.

Kalau dicermati eksistensi pendidikan Islam di Indonesia semenjak masa panjajahan sampai masa kemerdekaan ternyata di situ banyak lika-liku dan dinamika yang menghampirinya. Tetapi secara perlahan, pendidikan Islam terus

${ }^{20}$ Departemen Agama RI, Panduan Kurikulum Madrasah Aliyab1994, Jakarta : Depag RI, 1994), hlm 137

${ }^{21}$ Ibid 
dibenahi lewat berbagai regulasi dan upaya, sehingga ia terus tumbuh dan berkembang serta mampu berkontribusi untuk pembangunan bangsa. Dengan terbitnya UU Nomor 20 Tahun 2003 tentang Sistem Pendidikan Nasional dan UU Nomor 18 Tahun 2019 tentang Pesantren, maka pendidikan Islam mendapat ruang gerak yang lebih luas untuk berkembang dan berkualitas, serta berkontribusi lebih banyak untuk bangsa dan negara. Kedua undang-undang ini memberikan angin segar bagi pendidikan Islam, tetapi juga tidak akan terlepas dari berbagai rintangan dan tantangan.

\section{Kedudukan Pendidikan Islam dalam Sistem Pendidikan di Indonesia}

Dalam UU Nomor 20 Tahun 2003 diatur tentang kedudukan Pendidikan Islam sebagai mata pelajaran dan sebagai sebagai Sub Sistem Pendidikan Nasional. Agar lebih jelas perlu diuraikan satu persatu, yakni sebagai berikut:

\section{Pendidikan Islam sebagai Mata Pelajaran}

Istilah 'pendidikan agama Islam' di Indonesia dipergunakan untuk suatu nama mata pelajaran di lingkungan sekolah-sekolah yang berada di bawah pembinaan Kementerian Pendidikan Nasional. Pendidikan agama Islam masuk dalam struktur kurikulum Pendidikan Nasional. Ia termasuk ke dalam kelompok mata pelajaran wajib dalam setiap jalur jenis dan jenjang pendidikan, berpadanan dengan mata pelajaran lain seperti pendidikan kewarganegaraan, bahasa, matematika, sosial dan budaya. Memang semenjak proklamasi kemerdekaan Indonesia sampai terwujudnya Undang-undang nomor 2 Tahun 1989 tentang Sistem Pendidikan Nasional dan disempurnakan dengan Undang-undang nomor 20 Tahun 2003 tentang Sistem Pendidikan Nasional eksistensi pendidikan Islam sudah diakui oleh pemerintah sebagai mata pelajaran di Sekolah Dasar sampai Perguruan Tinggi. ${ }^{22}$

\section{Pendidikan Islam sebagai Sub Sistem Pendidikan Nasional}

Sistem pendidikan Islam di Indonesia merupakan bagian dari sistem pendidikan Nasional Indonesia. Hal itu diatur dalam pasal 15 Undang-Undang nomor 20 Tahun 2003 tentang Sistem Pendidikan Nasional, yang menyebutkan bahwa pendidikan umum, pendidikan kejuruan, pendidikan khusus, pendidikan magang, pendidikan keagamaan, pendidikan akademik, dan pendidikan profesi merupakan jalur pendidikan formal dalam sistem pendidikan nasional. ${ }^{23}$

22 Ramayulis, Ilmu Pendidikan Islam, (Jakarta : Kalam Mulia, 2013), hlm 74

${ }^{23}$ Undang-Undang Nomor 20 Tahun 2003 tentang Sistem Pendidikan Nasional 
Apabila pendidikan agama Islam di lingkungan lembaga/satuan pendidikan yang berada di bawah naungan Kementerian Pendidikan Nasional terwujud sebagai mata pelajaran, maka di lingkungan Kementerian Agama terwujud sebagai satuan pendidikan yang berjenjang naik mulai dari Taman Kanak-Kanak (Raudh al-Athfal), sampai ke Perguruan Tinggi (al-Jami'at). Pengertian pendidikan Keagamaan Islam di sini mengacu kepada satuan pendidikan keagamaan atau lembaga pendidikan keagamaan Islam. Sebagai sub sistem dari sistem pendidikan nasional, maka pendidikan Islam mempunyai tujuan khusus yang harus dicapai. Tercapainya tujuan tersebut akan menunjang tercapainya tujuan pendidikan nasional secara keseluruhan yag menjadi supra sistemnya. ${ }^{24}$ Selajutnya, visi pendidikan Islam tentu sejalan dengan visi pendidikan nasional. Dimana visi pendidikan nasional adalah mewujudkan manusia Indonesia yang bertakwa dan produktif sebagai anggota masyarakat Indonesia yang bhinneka. Sedangkan misi pendidikan Islam sebagai perwujudan dari visi tersebut adalah mewujudkan nilai-nilai keislaman di dalam pembentukan manusia Indonesia. Manusia Indonesia yang dicita-citakan adalah manusia yang saleh dan produktif. Hal ini sejalan dengan trend kehidupan abad 21, agama dan intelek akan saling bertemu. ${ }^{25}$ Dengan misi tersebut pendidikan Islam dapat menjadi alternatif apabila pendidikan lainnya tidak dapat mengejawantahkan nilai-nilai keislaman, karena memang pendidikan Islam mempunyai ciri khas, yaitu : suatu sistem pendidikan yang didirikan dengan hasrat untuk mengejawantahkan nilai-nilai keislaman, suatu sistem yang mengajarkan ajaran Islam, atau mengkombinasikan antara nilai-nilai keislaman dan ajaran Islam. ${ }^{26}$

Kalau dalam UU No. 2 Tahun 1989 tentang Sistem Pendidikan Nasional lembaga pendidikan keagamaan yang diakui eksistensinya hanya yang berada pada jalur pendidikan formal (sekolah). Namun dalam UU No. 20 Tahun 2003 tentang Sistem Pendidikan Nasional, Lembaga Pendidikan Keagamaan ini diakui dan dapat dilaksanakan bukan saja pada jalur pendidikan formal, tetapi juga pada jalur pendidikan non formal (pesantren, madrasah diniyah) dan dalam jalur pendidikan in-formal (keluarga). Dalam hal pengakuan terhadap lembaga pendidikan keagamaan, pasal 17 UU No.20 Tahun 2003 tentang Sisdiknas menyiratkan bahwa Madrasah Ibtidaiyah (MI) merupakan jenjang pendidikan yang setara dengan dengan Sekolah Dasar (SD), Madrasah Tsanawiyah (MTs) setara dengan Sekolah Menengah Pertama (SMP). Pasal 18 menyebutkan bahwa

\footnotetext{
${ }^{24}$ Zakiah Daradjat, Ilmu Pendidikan Islam, (Jakarta : Bumi Aksara, 2000), hlm 14

${ }^{25}$ Azyumardi Azra, Pendidikan Islam Tradisi dan Modernisasi Menuju Milenium Baru, (Jakarta : Logos Wacana Ilmu, 1999), hlm 39

${ }^{26}$ Muhammad Quthb, Sistem Pendidikan Islam, Alib Bahasa Salman Harun, (Bandung : AlMa'arif, 1984 ), hlm 15
} 
Madrasah Aliyah (MA) setara dengan Sekolah Menengah Atas (SMA) serta Madrasah Aliyah Keagamaan (MAK) setara dengan Sekolah Menengah Kejuruan (SMK). ${ }^{27}$

Pada prinsipnya pendidikan Islam hadir dengan tujuan untuk mengembangkan potensi manusia agar ia mampu mengemban dengan baik misi sebagai khalifah $f i$ al-ardh. Hal ini sejalan dengan misi Islam sebagai agama yang menebarkan rahmat bagi sekalian alam. Maka pendidikan Islam memiliki sasaran yang meliputi empat pengembangan fungsi manusia, yaitu : pertama, menyadarkan manusia secara individual pada posisi fungsinya di tengah makhluk lain, sertatanggungjawab dalam kehidupannya. Kedua, menyadarkan fungsi manusia dalam hubungannya dengan masyarakat serta tanggung jawabnya terhadap ketertiban masyarakat. Oleh karena itu manusia harus mengadakan interrelasi dan interaksi dengan sesamanya. Ketiga, menyadarkan manusia terhadap pencipta alam dan mendorongnya untuk beribadah kepada-Nya. Keempat,menyadarkan manusia tentang kedudukannya terhadap makhluklain dan membawanya agar memahami hikmah Tuhan menciptakan makhluk lain serta memberikan kemungkinan kepada manusia untuk mengambil manfaatnya. Karena Islam menggolongkan pendidikan sebagai tugas suci maupun penyerahan diri terhadap Allah, maka dengan keteguhan hati diharapkan mampu memotivasi umat untuk mengaktualisasikan imannya kepada Allah dalam situasi dan kondisi apapun. Oleh sebab itu visi pendidikan Islam tidak diarahkan oleh pragmatisme, namun oleh keteguhan hati dan cinta kepada Allah SWT. ${ }^{28}$

\section{Kedudukan Pesantren Sebagai Lembaga Pendidikan Islam di Indonesia}

Kedudukan pesantren sebagai lembaga pendidikan Islam di Indonesia diatur secara spesifik dalam Undang-Undang Nomor 18 Tahun 2019 tentang Pesantren yang diterbitkan tanggal 18 Oktober 2019. ${ }^{29}$ Undang-undang ini mengatur banyak hal tentang pesantren, terutama tentang: pengertian pesantren, pendirian, pembiayaan dan pendanaan, penyelenggaraan, fungsi, jenjang pendidikan, kurikulum, dan masa depan lulusannya.

\section{Pengertian Pesantren dan Pendidikan Pesantren}

Undang-UndangNomor 18 Tahun 2019 memberikan defenisi yang jelas tentang pesantren dan lembaga pendidikan pesantren. Bahkan lebih dari itu, undang-undang ini juga memberikan kepastian hukum tentangkedudukan

\footnotetext{
${ }^{27}$ Undang-Undang Nomor 20 Tahun 2003 tentang Sistem Pendidikan Nasional

${ }^{28}$ Abdullah Idi dan Suharto Ito, Revitalisasi Pendidikan Islam, (Yogyakarta : Tiara Wacana, 2006), hlm 55

${ }^{29}$ Undang-Undang Nomor 18 Tahun 2019 tentang Pesantren
} 
pesantren serta fungsinya di Negara Kesatuan Republik Indonesia. Di mana negara menjamin dan melindungi kedudukan pesantren sebagai bagian dari lembaga pendidikan yang berfungsi untuk mencerdaskan kehidupan bangsa, serta berperan sebagai wadah pembentukan karakter anak-anak bangsa dengan mengintegrasikan nilai-nilai keislaman dan keindonesiaan.

Terkait pengertian pesantren, maka pada pasal 1 ayat 1 UU Nomor 18 Tahun 2019 disebutkan bahwa: "Pondok Pesantren, Dayah, Surau, Meunasah, atau sebutan lain yang selanjutnya disebut Pesantren adalah lembaga yang berbasis masyarakat dandidirikan oleh perseorangan, yayasan, organisasi masyarakat Islam, dan/atau masyarakat yang menanamkan keimanan dan ketakwaan kepada Allah Swt., menyemaikan akhlak mulia serta memegang teguh ajaran Islam rahmatan lil'alamin yang tercermin dari sikap rendah hati, toleran, keseimbangan, moderat, dan nilai luhur bangsa Indonesia lainnya melalui pendidikan, dakwahIslam, keteladanan, dan pemberdayaan masyarakatdalam kerangka Negara Kesatuan Republik Indonesia". Sedangkan pengertian pendidikan pesantren diatur pada pasal 1 ayat 2 yang menyebutkan bahwa "Pendidikan Pesantren adalah pendidikan yang diselenggarakan oleh Pesantren dan berada di lingkungan Pesantren dengan mengembangkan kurikulum sesuai dengan kekhasan Pesantren dengan berbasis kitab kuning atau dirasah Islamiah dengan pola pendidikan muallimin".

\section{Mendirikan Pesantren}

Masyarakat memiliki hak dan kesempatan yang luas untuk mendirikan lembaga pendidikan pesantren baik secara perseorangan, yayasan, organisasi masyarakat Islam, dan atau secara bersama-sama. Hal ini diatur dalam Pasal 6UU Nomor 18 Tahun 2019, pada beberapa ayat sebagai berikut:

1. Pesantren didirikan oleh perseorangan, yayasan, organisasi masyarakat Islam, danatau masyarakat.

2. Pendirian Pesantren sebagaimana dimaksud padaayat (1) wajib:

a. berkomitmen mengamalkan nilai Islam rahmatanlil'alamin dan berdasarkan Pancasila, Undang-Undang Dasar Negara Republik Indonesia Tahun1945, Negara Kesatuan Republik Indonesia, sertaBhinneka Tunggal Ika;

b. memenuhi unsur Pesantren sebagaimanadimaksud dalam Pasal 5 ayat (21;

c. memberitahukan keberadaannya kepada kepaladesa atau sebutan lain sesuai dengan domisiliPesantren; dan

d. mendaftarkan keberadaan Pesantren kepada menteri 
3. Dalam hal pendirian Pesantren sebagaimanadimaksud pada ayat (2) terpenuhi, Menterimemberikan izin terdaftar.

Hak untuk mendirikan pesantren sebagaimana diatur oleh undangundang tersebut di atas dapat dilaksanakan selama mematuhi segala ketentuan yang berlaku dan memenuhi semua persyaratan yang ditentukan. Salah satu hal yang substansial dalam persyaratan mendirikan pesantren adalah komitmen untuk mengamalkan nilai Islam yang rahmatan lil'alamin dalam bingkai Negara Kesatuan Republik Indonesia, berdasarkan Pancasila dan UUD Tahun 1945, serta menjunjung tinggi semangat kebhinekaan.

\section{Pembiayaan dan Pendanaan Pesantren}

Kalau selama ini ada pesantren yang kesulitan untuk sekedar mempertahankan eksistensinya di tengah masyarakat karena kesulitan finansial, maka dengan terbitnya UU Nomor 18 Tahun 2019 pesantren memiliki ruang yang cukup luas untuk mencari dukungan finansial dari berbagai pihak, sehingga dengan finansial yang memadai pesantren dapat mengembangkan diri dan meningkatkan kiprahnya secara efektif. Untuk itu, pesantren dalam menjalankan visi dan misinya perlu bersinergi dengan berbagai lapisan masyarakat, pemerintah daerah dan pemerintah pusat.

Pemerintah bersama DPR telah membuat payung hukum tentang pembiayaan dan pendanaan pesantren, sebagaimana diatur dalam UU Nomor 18 Tahun 2019 Pasal 11, 12, 42, 46, 48 dan 49. Pada pasal 11 ayat 3 disebutkan bahwa: "Pemerintah Pusat dan Pemerintah Daerah sesuai dengan kewenangannya dapat memfasilitasi pondok atau asrama Pesantren untuk memenuhi aspek daya tampung, kenyamanan, kebersihan, kesehatan, dan keamanan. Lalu pada pasa 12 ayat 2 disebutkan bahwa: "Pemerintah Pusat dan Pemerintah Daerah sesuaidengan kewenangannya dapat memfasilitasi masjid atau musala Pesantren untuk memenuhi aspek dayatampung, kenyamanan, kebersihan, kesehatan, dan keamanan.

Sementara itu pada Pasal 46 diatur sebagai berikut:

1. Pemerintah Pusat dan Pemerintah Daerahmemberikan dukungan dan fasilitasi ke Pesantrendalam melaksanakan fungsi pemberdayaanmasyarakat.

2. Dukungan Pemerintah Pusat dan PemerintahDaerah sebagaimana dimaksud pada ayat (1) palingsedikit berupa:

a. bantuan keuangan;

b. bantuan sarana dan prasarana; 
c. bantuan teknologi; dan/atau

d. pelatihanketerampilan.

Sedangkan pada Pasal 48 diatur sebagi berikut:

1. Sumber pendanaan penyelenggaraan Pesantrenberasal dari masyarakat.

2. Pemerintah Pusat membantu pendanaanpenyelenggaraan Pesantren melalui anggaranpendapatan dan belanja negara sesuai dengankemampuan keuangan negara dan ketentuanperaturan perundang-undangan.

3. Pemerintah Daerah membantu pendanaanpenyelenggaraan Pesantren melalui anggaranpendapatan dan belanja daerah sesuai dengankewenangannya dan ketentuan peraturanperundang-undangan.

4. Sumber pendanaan penyelenggaraan Pesantrendapat berasal dari sumber lain yang sah dan tidakmengikat sesuai dengan ketentuan peraturanperundangundangan.

5. Sumber pendanaan Pesantren yang berasal dari hibah luar negeri diatur lebih lanjut dalam

\section{Peraturan Presiden}

Selanjutnya dalam Pasal 49 disebutkan:

1. Pemerintah menyediakan dan mengelola dana abadi Pesantren yang bersumber dan merupakan bagiandari dana abadi pendidikan.

2. Ketentuan mengenai dana abadi Pesantrensebagaimana dimaksud pada ayat (1) diatur denganPeraturan Presiden.

Masalah pendanaan pesantren juga diatur pada Pasal 42, yang mengatakan bahwa: "Pemerintah Pusat dan Pemerintah Daerah memberikan dukungan pelaksanaan fungsi dakwah Pesantren dalam bentuk kerja sama program, fasilitasi kebijakan, dan pendanaan".

\section{Penyelenggaraan Pesantren}

Dalam menjalankan visi dan misinya pesantren berhak menjaga dan mempertahankan kekhasan atau keunikan yang dimilikinya sesuai dengan tradisi yang dibangun, kehendak dan cita-cita luhur, serta ragam dan karakteristiknya. Namun bersamaan dengan itu pesantren mesti mengembangkan nilai Islam yang rabmatan lil 'alamin dengan semangat keindonesiaan, dalam bingkai Negara Kesatuan Republik Indonesia (NKRI), berdasarkan Pancasila dan UUD 1945 serta menjunjung tinggi semangat kebhinekaan. Persyaratan ini merupakan harga mati dalam penyelengaraan pendidikan pesantren, supaya pesantren dapat melahirkan generasi terpelajar yang religius dan nasionalis dalam bingkai NKRI. 
Undang-Undang Nomor 18 Tahun 2019 mengatur tentang penyelenggaraan pesantren sebagaimana termaktub pada pasal 8 ayat 1 , yang menyebutkan bahwa: "Penyelenggaraan Pesantren wajib mengembangkan nilai Islam rahmatan lil'alamin serta berdasarkanPancasila, Undang-Undang Dasar Negara Republik Indonesia Tahun 1945, Negara Kesatuan Republik Indonesia, dan Bhinneka Tunggal Ika".

Sementara itu pada pasal 8 ayat 2 yang disebutkan bahwa :" Penyelenggaraan Pesantren sebagaimana dimaksudpada ayat (1) dilaksanakan dengan tetap menjaga kekhasan atau keunikan tertentu yang mencerminkan tradisi, kehendak dan cita-cita, serta ragam dan karakter Pesantren.”

\section{Fungsi Pesantren}

Undang-Undang Nomor 18 Tahun 2019 mengatur bahwa pesantren berfungsi sebagai bagian dari penyelenggaraan pendidikan nasional berdasarkan kekhasan, tradisi, dan kurikulum pendidikannya. Hal ini termaktub pada Pasal 15, yang menyebutkan bahwa :'Pesantren melaksanakan fungsi pendidikan sebagaibagian dari penyelenggaraan pendidikan nasional". Sedangkan pada Pasal 16 ayat 1 disebutkan bahwa :" Pesantren menyelenggarakan fungsi pendidikan berdasarkan kekhasan, tradisi, dan kurikulum pendidikan masing-masing Pesantren".

Payung hukum ini memberikan kesempatan luas kepada pesantren untuk melaksanakan pendidikan sesuai dengan kekhasan yang dimiliki, tradisi yang mereka bangun, serta kurikulum yang mereka kembangkan sendiri. Dengan demikian pesantren berkesempatan untuk dapat mengembangkan diri sesuai dengan cita-cita luhurnya,serta dapat membuat warna tersendiri dalam dunia pendidikan Indonesia. Semua ini tentunya tidak boleh terlepas dari nilai-nilai keislaman dan keindonesiaan.

\section{Jenjang Pendidikan Pesantren}

UU Nomor 18 Tahun 2019 tidak hanya mengakomodir dan mengakui kedudukan pesantren yang formal, tetapi juga mengakomodir dan mengakui kedudukan pesantren non formal (yang hanya melaksanakan pengkajian kitab kuning). Dengan demikian pesantren yang selama ini melaksanakan pengkajian kitab kuning tidak perlu risau dengan masa depan lembaganya, tidak perlu risau dengan prospek alumninya ke depan, serta tidak perlu latah merubah orientasi dan karakteristik lembaganya demi kepentingan pragmatis. 
Jenjang pendidikan pesantren sudah diatur dalam Undang-Undang Nomor 18 Tahun 2019 pada Pasal 17 sebagai berikut :

1. Pesantren menyelenggarakan pendidikan formal dan atau nonformal.

2. Pendidikan formal sebagaimana dimaksud pada ayat (1) meliputi Pendidikan Pesantrenjenjang pendidikan dasar, menengah, dan tinggi.

3. Pendidikan Pesantren yang diselenggarakan padajalur pendidikan formal jenjang pendidikan dasar sebagaimana dimaksud pada ayal (2) berbentuk:

a. satuan Pendidikan Muadalah ula atauPendidikan Diniyah Formal ula; dan/atau

b. satuan Pendidikan Muadalah wustha atauPendidikan Diniyah Formal wustha.

4. Pendidikan Pesantren yang diselenggarakan padajalur pendidikan formal jenjang pendidikan menengah sebagaimana dimaksud pada ayat (2) berbentuk satuan Pendidikan Muadalah ulya atauPendidikan Diniyah Formal ulya.

5. Jenjang Pendidikan Muadalah dapat diselenggarakan dalam waktu 6 (enam) tahun atau lebih dengan menggabungkan penyelenggaraan satuan Pendidikan Muadalah wustha dan satuan Pendidikan Muadalah ulya secara berkesinambungan.

6. Pendidikan Pesantren yang diselenggarakan padajalur pendidikan formal jenjang pendidikan tinggi sebagaimana dimaksud pada ayat $(21$ berbentuk Ma'had A1y.

7. Pendidikan nonformal sebagaimana dimaksud padaayat (1) berbentuk pengkajian Kitab Kuning.

Sedangkan Pada Pasal 23 ayat 1 disebutkan bahwa: "Pendidikan Pesantren jalur pendidikan nonformal dapat diselenggarakan secara berjenjang atau tidak berjenjang".

\section{Kurikulum Pesantren}

UU Nomor 18 Tahun 2019 memberi ruang kepada pesantren untuk mengembangkan kurikulum sendiri sesuai dengan ide dan orientasinya. Setiap pesantren diberikan kesempatan yang sama untuk itu. Sehingga setiap pesantren berhak menentukan arah pendidikan yang dilaksanakannya.

Undang-Undang Nomor 18 Tahun 2019 telah mengatur tentang kurikulum pesantren sebagaimana termaktub pada Pasal 18 sebagai berikut :

1. KurikulumPendidikan Muadalah terdiri terdiri darikurikulum Pondok Pesantren dan pendidikan umum 
2. Kurikulum Pesantren sebagaimana dimaksud pada ayat (1) dikembangkan oleh Pesantren dengan berbasis Kitab Kuning atau Dirasah Islamiah dengan Pola Pendidikan Muallimin.

3. Kurikulum pendidikan umum sebagaimana dimaksud pada ayat (1) diatur dalam Peraturan Menteri.

Sementara itu pada Pasal 20 diatur sebagai berikut:

1. Kurikulum Pendidikan Diniyah Formal terdiri atas kurikulum Pesantren dan kurikulum pendidikanumum.

2. Penyusunan rumusan kerangka dasar dan struktur kurikulum Pesantren sebagaimana dimaksud pada ayat (1) yang berbasis Kitab Kuning dilakukan oleh Majelis Masyayikh.

3. Kurikulum pendidikan umum sebagaimana dimaksud pada ayat (1) diatur dalam Peraturan Menteri.

Selanjutnya pada Pasal 22 diatur sebagai berikut :

1. Ma'had Aly menyelenggarakan pendidikan akademik pada program sarjana, magister, dan doktor.

2. Ma'had Aly mengembangkan rumpun ilmu agama Islam berbasis Kitab Kuning dengan pendalaman bidang ilmu keislaman tertentu.

3. Pendalaman bidang ilmu keislaman yang diselenggarakan oleh Ma'had Aly yang dikembangkan berdasarkan tradisi akademik Pesantren dalam bentuk konsentrasi kajian.

4. Mahad Aly dapat menyelenggarakan lebih dari 1 (satu) konsentrasi kajian pada 1 (satu) rumpun ilmu agama Islam.

5. Kurikulum Ma'had AIy wajib memasukkan materi muatan Pancasila, kewarganegaraan, dan Bahasa Indonesia.

6. Ma'had Aly memiliki otonomi untuk mengelola lembaganya sebagaimana tertuang dalam statuta Ma'had Aly.

7. Santri Ma'rad Aly yang telah menyelesaikan proses pembelajaran dan dinyatakan lulus berhak menggunakan gelar dan mendapatkan ijazah serta berhak melanjutkan pendidikan pada program yang lebih tinggi dan kesempatan kerja.

\section{Masa Depan Lulusan Pesantren}


Lulusan pesantren tidak perlu pesimis dengan masa depan mereka, baik untuk melanjutkan studi ke jenjang yang lebih tinggi maupun untuk mendapatkan kesempatan kerja, karena UU Nomor 18 Tahun 2019 menjadi payung hukum bagi status lulusan pesantren. Di mana lulusan pesantren baik formal maupun nonformal memiliki hak dan kesempatan yang sama dengan lulusan lembaga pendidikan lainnya untuk melanjutkan studi ke jenjang yang lebih tinggi baik yang sejenis maupun tidak sejenis, dan atau kesempatan kerja. berikut:

Hal ini diatur dalam UU Nomor 18 Tahun 2019 pada Pasal 19 sebagai

1. Santri satuan Pendidikan Muadalah yang telah menyelesaikan pendidikan dinyatakan lulus melalui penilaian oleh pendidik dan satuan Pendidikan Muadalah.

2. Santri yang dinyatakan lulus sebagaimana dimaksud pada ayat (1) berhak:
a. melanjutkan ke jenjang pendidikan yang lebihtinggi baik yang sejenis maupun tidak sejenis;dan/atau
b. mendapatkan kesempatan kerja.

Sementara itu pada Pasal 21 diatur sebagai berikut:

1. Santri satuan Pendidikan Diniyah Formal yang telahmenyelesaikan pendidikan dinyatakan lulus melalui penilaian oleh pendidik, satuan pendidikan formal,dan penilaian oleh Menteri.

2. Para peserta didik di Pesantren yang telah lulus sesuai dengan dimaksud pada ayat (1) berhak:

a. Meneruskan ke jenjang pendidikan yang lebihtinggi baik yang sejenis maupun tidak sejenis;dan/atau

b. diberikan kesempatan kesempatan kerja.

Status lulusan pesantren juga diatur pada pada Pasal 23 ayat 2-4 sebagai berikut:

1. Pendidikan Pesantren melalaui jalur nonformal dapat menerbitkan syahadah atau ijazah sebagai tanda kelulusan.

2. Alumni Pendidikan Pesantren jalur pendidikan nonformal dapat diakui sama dengan pendidikan formal pada jenjang tertentu setelah lulus ujian.

3. Alumni Pesantren jalur pendidikan nonformal yang telah lulus ujian seperti yang tertera pada ayat (3) bisa meneruskan pendidikan formal yang lebih tinggi, baik yang sejenis maupun tidak sejenis, dan/atau kesempatan kerja. 
Seiring dengan adanya perlakuan yang sama antara lulusan pesantren dengan lulusan lembaga pendidikan lainnya maka pengelola pesantren dituntut untuk bersungguh-sungguh dalam membekali lulusannya dengan berbagai keahlian agar mereka mampu bersaing dengan lulusan lembaga pendidikan lainnya. Kesungguhan itu diwujudkan dalam bentuk pengembangan kurikulum secara efektif, melengkapi sarana dan prasarana, meningkatkan kualitas tenaga pendidik dan tenaga kependidikan, memperbaharui model pembelajaran, meningkatkan mutu lulusan, dan lain-lain. Agaknya kesungguhan itu juga perlu dimiliki oleh para santri (dalam belajar), serta para orang tua santri dalam membimbing anaknya. Sebab tidak ada artinya peluang yang diberikan oleh undang-undang kalau ternyata lulusan pesantren tidak siap untuk berkompetisi.

Kalau dicermati UU Nomor 18 Tahun 2019 secara utuh dan komprehensif, maka dipahami bahwa pesantren mendapat ruang yang luas untuk memperlihatkan eksistensiya, mengembangkan diri, meningkatkan mutu lulusan, berkreasi dan berinovasi, serta memberikan kontribusi nyata untuk pembangunan bangsa melalui dunia pendidikan. Sebab, UU Nomor 18 Tahun 2019 memberikan kepastian hukum terhadap kedudukan dan eksistensi pesantren di Indonesia.

\section{Problematika Pendidikan Islam}

Meskipun pendidikan Islam telah diberikan kesempatan luas untuk berkembang oleh negara sejalan dengan tuntutan hidup kultural bangsa, namun masih terdapat problema dalam operasionalnya. Menurut Hanipudin, salah satu sebab ketertinggalan pendidikan Islam di Indonesia dalam mendampingi laju modernitas adalah kurang cepatnya proses penyerapan terhadap ilmu pengetahuan umum. Hal ini tak lepas dari pengaruh dikotomik pendidikan yang diwariskan penjajah, yaitu antara lain dikotomisasi pendidikan, anggaran yang tidak proporsional, marjinalisasi pendidikan Islam, dan lain-lain. ${ }^{30}$

Problematika pendidikan Islam di Indonesia disebabkan oleh dua faktor, yaitu faktor eksternal dan faktor internal.

\section{Faktor Eksternal}

Ada beberapa faktor eksternal yang menjadi problema bagi pendidikan Islam di Indonesia, yakni sebagai berikut:

1. Timbulnya sikap masyarakat di beberapa lingkungan sekitar sekolah yang kurang concern kepada urgensi pendidikan agama, tidak acuh terhadap

${ }^{30}$ Sarno Hanipudin, op.cit, hlm. 12 
pemantapan pendidikan agama di sekolah, dan sikap ini berlanjut sampai di rumah tangga. Sikap masyarakat seperti ini disebabkan oleh dampak kebutuhan ekonomi yang mendorongnya untuk bekerja di luar rumah dengan durasi yang lama, sehingga mereka menyerahkan sepenuhnya pendidikan anak kepada sekolah. Padahal pendidikan agama di sekolah (khususnya sekolah umum) hanya berlangsung selama 2 jam pelajaran seminggu.

2. Situasi lingkungan sekolah dinodai oleh perilaku yang tidak baik dengan berbagai ragamnya, seperti tontonan yang tidak mendidik, yang mudah diakses setiap saat. Situasi demikian dapat melemahkan daya konsentrasi berfikir dan berakhlak mulia, serta mengurangi gairah belajar, bahkan mengurangi daya bersaing dalam meraih kemajuan.

3. Gaya hidup yang suka mengambil jalan pintas meluas ke arah jalur kehidupan remaja, misalnya budaya "nyontek" membeli soal-soal ujian akhir dengan harga tinggi, dan lain-lain.

4. Tingginya sikap pesimis di kalangan orang tua atau masyarakat bahwa pendidikan yang tinggi yang terkadang didapatkan dengan susah payah tidak menjamin anaknya untuk mendapatkan pekerjaan yang layak, disebabkan perluasan lapangan kerja tidak dapat mengimbangi pertumbuhan usia kerja. Semua itu menyebabkan tendensi sosial kurang menghargai pendidikan sekolah yang tidak dapat dijadikan tumpuan harapan masa depan, sementara persaingan semakin ketat dalam memperebutkan lapangan kerja. Kondisi ini membuat pendidikan agama terkena dampak negatif dari sikap dan kecenderungan masyarakat.

5. Serbuan dampak kemajuan ilmu pengetahuan dan teknologi melalui berbagai media semakin merenggangkan manusia dengan agama, serta memperlebar kesenjangan antara nilai tradisional dengan nilai rasional teknologis, menjadi sumber transisi nilai yang arahnya belum menentu. Di tengah arus globalisasi peserta didik telah menjadi masyarakat global. Mereka telah mendapat banyak pengaruh dari dunia global sekarang. Tayangan TV, video, film, bacaan, komputer secara sadar atau tidak sadar mereka telah masuk menjadi bagian dari budaya global..$^{31}$ Sementara itu teknologi pendidikan atau pendidikan teknologi telah menyerbu sampai bangku sekolah dengan berbagai dampaknya. Sikap anak didik dalam mengambil jalan terobosan untuk mengatasi kesulitan berfikir yang kreatif dan analitis ditempuh melalui mesinmesin berfikir seperti komputer, kalkulator, dan robot-robot yang dapat berfikir lebih cepat dari manusia. Ini adalah beberapa contoh dari orientasi

${ }^{31}$ Haidar Putra Daulay, Pendidikan Islam dalam Sistem Pendidikan Nasional di Indonesia, ( Jakarta: Prenada Media, 2004), hlm 228 
belajar yang tidak mendorong ke arah pencerdasan generasi muda. Sistematisasi belajar atas dasar efesiensi yang tinggi juga berdampak negatif terhadap pendidikan, seperti pendidikan sekolah yang dicapai dengan waktu yang singkat dengan dana yang seminimal mungkin namun berhasil meluluskan siswa dengan jumlah yang lebih besar. Ini adalah salah satu contoh penerapan efesiensi industrial teknologis yang kurang mengacu kepada kaidah hukum perkembangan berdasarkan tempo dan kesatuan organis serta hukum konvergensi. Setiap siswa punya corak dan potensi dasar berkembang yang tidak sama satu sama lainnya. Sedangkan untuk penerapan efesiensi pendidikan tersebut tidak disediakan dengan sempurna input instrumennya.

Dalam hal yang menyangkut pendidikan agama, sasaran proses pendidikan kurang mendapatkan tempat yang wajar dalam sistem efesiensi tersebut. Tidak mungkin pendalaman nilai iman dan takwa manusia diproses melalui pendekatan prosedur pengembangan sistem instruksional, sebab nilainilai tersebut tidak dapat dipribadikan melalui proses formal kognitif, afektif dan psikomotorik semata, melainkan justru penciptaan suasana keagamaan dan contoh keteladanan lebih berdaya guna dalam proses pendidikan agama. ${ }^{32}$

\section{Faktor Internal}

Faktor internal yang menjadi problem bagi pendidikan Islam adalah sebagai berikut:

1. Kurang memadainya sarana dan prasarana. Tidak dapat dipungkiri bahwa banyak sekolah agama (madrasah atau pesantren) yang minim sarana dan prasarana, berupa minimnya ruang belajar yang representatif, tidak ada laboratorium, perpustakaan yang memadai, dan sarana pendukung lainnya.

2. Kurangnya tenaga pengajar, baik secara kuantitas maupun kualitas. Secara kuantitas sekolah agama mengalami kekurangan guru karena kurangnya jumlah pengangkatan guru madrasah, atau kurangnya penempatan guru ASN di pondok pesantren, dan di sisi lain madrasah dan pondok pesantren kesulitan mencari biaya untuk menggaji guru-guru honor. Sedangkan kekurangan tenaga pengajar secara kualitas disebabkan karena rendahnya kompetensi mereka, misalnya ketika pondok pesantren ingin mengembangkan pengajaran kitab kuning ide tersebut terganjal oleh minimnya guru yang mampu menyukseskan program tersebut. Selain itu

${ }^{32}$ H.M. Arifin, Pendidikan Islam dalam Arus Dinamika Masyarakat, (Jakarta : Golden Terayon Press, 1991), hlm 93 
kurangnya kompetensi guru disebabkan oleh rendahnya keinginan dan usaha mereka untuk meningkatkan kualitas diri.

3. Pendekatan metodologis guru masih terpaku kepada orientasi tradisionalistik sehingga tidak mampu menarik minat siswa kepada pelajaran agama.

4. Kurangnya rasa solidaritas antara guru agama dengan guru-guru bidang studi umum, sehingga tidak terwujud kolaborasi antara sesama guru yang mengakibatkan pelaksanaan pendidikan agama tidak efektif.

5. Kurikulum madrasah sebagai hasil adopsi dari kurikulum sekolah umum terlalu padat dan berat. "Beban" itu semakin berat ketika ditambah dengan muatan lokal lembaga yang juga menuntutkemampuan pemahaman yang baik.

6. Lemahnya kemampuan manajemen dikalangan pengelola lembaga pendidikan Islam.

7. Pemerataan pendidikan bagi seluruh lapisan masyarakat masih perlu diintensifkan melalui pendekatan integralistik yang lebih menekankan pada kualitas ketimbang kuantitas semenjak pendidikan dasar sampai pendidikan tinggi, oleh karena tuntutan pembangunan masa depan semakin memerlukan manusia Indonesia yang berkualitas tinggi, baik dalam aspek ilmu pengetahuan maupun dalam sikap mental dimana iman dan takwa sebagai sumber pendorong yang utama. ${ }^{33}$

\section{Solusi dan Strategi dalam Pengembangan Pendidikan Islam}

Berkaitan dengan problematika pendidikan Islam, maka para pegiat atau praktisi pendidikan Islam perlu melakukan berbagai inovasi untuk mengatasi berbagai masalah itu. Inovasi yang dilakukan tidak hanya berkaitan dengan sarana dan prasarana serta Sumber Daya Manusia, tetapi juga menyangkut dengan perangkat kurikulum dan manajemen, sertastrategi dan taktik operasionalnya. Strategi dan taktik itu menuntut perombakan model-model pembelajaran sampai dengan institusi-institusinya, sehingga lebih efektif dan lebih efesien, dalam arti paedagogis, sosiologis dan kultural dalam menunjukkan perannya. ${ }^{34}$ Untuk itu, ada beberapa hal yang dapat dilakukan sebagai solusi dan strategi dalam pengembangan pendidikan Islam, yakni sebagai berikut:

1. Melakukan reinterpretasi terhadap sumber utama pendidikan Islam, yaitu alQur'an dan Hadits. Suatu interpretasi baru yang berorientasi kepada tiga

\footnotetext{
${ }^{33} \mathrm{Ibid}$, hlm 95

${ }^{34}$ H.M.Arifin, Kapita Selekta Pendidikan Islam dan Umum, ( Jakarta : Bumi Aksara, 1991), $\operatorname{hlm} 3$
} 
kemampuan dasar manusia, yaitu kognitif, afektif dan psikomotorik. Disamping itu keterjalinan antara nilai-nilai kepribadian bangsa dengan nilainilai keislaman lebih diperkokoh lagi sehingga dapat mewujudkan manusia muslim yang pancasilais sejati. Konsep manusia seutuhnya yang menurut pandangan Islam yang mengacu ke dalam falsafah Pancasila perlu dipolakan secara jelas dan selaras sehingga tidak menimbulkan konflik bathiniah yang berakibat kepada dis-oriented personality.

2. Pembelajaran dalam pendidikan Islam juga perlu menggunakan pendekatan terpadu. Pembelajaran terpadu ini merupakan suatu aplikasi salah satu strategi pembelajaran berdasarkan pendekatan kurikulum terpadu yang bertujuan untuk menciptakan atau membuat proses pembelajaran secara relevan dan bermakna bagi siswa. Pembelajaran ini didasarkan pada pendekatan inquiry, yaitu melibatkan siswa mulai dari merencanakan, mengeksplorasi, dan brain storming dari siswa. Dengan pendekatan terpadu siswa didorong untuk berani bekerja secara berkelompok dan belajar dari hasil pengalamannya sendiri. Dalam pelaksanaannya siswa dapat diajak bepartisipasi aktif dalam mengeksplorasi topik atau kejadian, siswa belajar proses dan isi (materi) lebih dari satu sub-bidang studi pada waktu yang sama. ${ }^{35}$

3. Faktor struktural kelembagaan pendidikan Islam yang telah eksis dalam masyarakat perlu dilakukan inovasi yang dapat mendukung tujuan pendidikan nasional. Tujuan pendidikan, metode dan konten perlu diperbarui sedemikian rupa sehingga mampu menarik minat anak didik tanpa mengurangi prinsipprinsip ajaran dari sumber pokok Islam. Kelenturan dari struktur kelembagaan pendidikan Islam seperti pesantren atau madrasah sebagai ciri khas Indonesia, memiliki orientasi ke arah faktor tersebut. Bukan hanya pesantren plus sekolah umum atau madrasah plus pengetahuan umum seperti yang telah dianut oleh umat Islam di beberapa lingkungan masyarakat, akan tetapi suatu model pesantren yang berfungsi ganda ; ia merupakan lembaga sosial keagamaan Islam berfungsi sebagai pusat pembinaan mental agama masyarakat sekitar yang berorientasi kepada modernisasi umat, sekaligus menjadi lembaga pendidikan agama Islam, ia berfungsi sebagai pusat pemberdayaan umat melalui agama Islam di lingkungan yang dinamis dan aspiratif terhadap tuntutan kemajuan lahiriah dan batiniah.

4. Faktor teknis operasional pendidikan agama di semua jenjang pendidikan umum perlu lebih diaktualisasikan ke dalam proses yang integralistik dengan pendidikan intelektual dan keterampilan sehingga terwujud keserasian dan

35 Muhaimin, Nuansa Baru Pendidikan Islam : Mengurai Benang Kusut Dunia Pendidikan, (Jakarta : Raja Grafindo Persada, 2006), hlm 175 
keselarasan dalam pencapaian tujuan pendidikan nasional. Untuk itu kerjasama antara pelaksana pendidikan di sekolah perlu ditingkatkan, terutama dalam kegiatan belajar mengajar. Strategi pendidikan di sekolah kejuruan yang programnya lebih bersifat teknologis dan eksak perlu lebih intensif diimbangi dengan program pendidikan yang lebih moralis dan sosialistis- agamis tanpa menghilangkan ciri-ciri kejuruannya. ${ }^{36}$

5. Penataan sistem dan model-model pendidikan Islam merupakan sebuah keniscayaan. Sistem pengembangan pendidikan Islam hendaknya dipilih dari kegiatan yang paling mendesak dan sentral yang akan menjadi model dasar untuk usaha pengembangan model-model pendidikan Islam selanjutnya. Apabila dicermati model-model pendidikan Islam sekarang ini setidaknya berbasis pada empat jenis lembaga yang dapat mengambil peran dalam memberdayakan umat, yaitu pondok pesantren, pendidikan Islam berbasis mesjid, pendidikan Islam berbasis madrasah atau sekolah, dan pendidikan Islam berbasis pada pendidikan umum bernafaskan Islam. ${ }^{37}$

6. Membenahi sarana dan prasarana sehingga mendekati standar ideal. Lembaga pendidikan Islam perlu menciptakan keseimbangan antara jumlah anak didik dengan sarana dan prasarana. Langkah awal untuk itu bisa dilakukan dengan membatasi penerimaan peserta didik baru agar tidak melebihi kapasitas. Selanjutnya lembaga pendidikan perlu membenahi sarana dan prasarana dengan menggaet dana pemerintah dan melibatkan peran serta masyarakat melalui komite sekolah, perantau, dan alumni. Khusus pesantren, pemerintah sudah membuat regulasi dalam pembiayaan dan pendanaannya. Hal itu tertuang pada UU No. 18 Tahun 2019 Pasal 11, 12, 42, 46, 48 dan 49. Pada prinsipnya undang-undang ini memberikan peluang besar kepada pesantren untuk mendapatkan bantuan fisik dan finansial dari pemerintah pusat dan pemerintah daerah, serta masyarakat.

7. Meningkatkan kualitas tenaga pendidik dan tenaga kependidikan. Lembaga pendidikan Islam perlu meningkatkan kualitas tenaga pendidik dan tenaga kependidikannya. Sebagai langkah awal untuk mendapatkan tenaga pendidik dan tenaga kependidikan yang berkualitas, lembaga pendidikan perlu melakukan rekrutmen berdasarkan kualifikasi dan kualitas. Rekrutmen perlu mempertimbangkan kecocokkan antara kebutuhan dengan kualifikasi pendidikan dan kualitas. Untuk itu diperlukan transparansi serta standar yang jelas dan akuntabel dalam rekrutmen. Pada tahap berikutnya perlu

${ }^{36}$ HM. Arifin, Op.Cit. hlm 96

${ }^{37}$ Suroyo, Berbagai Persoalan Pendidikan; Pendidikan Nasional dan Pendidikan Islam di Indonesia, Jurnal Pendidikan Islam, Kajian tentang Konsep Pendidikan Islam, Problem dan Prospeknya, Volume 1 Tahun 1991, Fakultas Tarbiyah IAIN, Yogyakarta 
menempatkan seseorang sesuai dengan bidangnya (the right man on the right place), serta melakukan pembinaan secara berkala.

8. Lembaga pendidikan Islam perlu menerapkan konsep boarding school dan mengembangkan program unggulan. Pembinaan terhadap anak didik perlu dilakukan dengan waktu yang memadai. Kalau hanya mengandalkan jam pelajaran di sekolah maka waktu yang tersedia untuk pembinaan akan sangat minim. Selain itu, ketika anak didik pulang dari sekolah ia akan lepas dari pengawasan pihak sekolah, apalagi kalau orang tuanya sibuk dengan pekerjaan masing-masing tentu anak didik berada di luar pengawasan. Oleh sebab itu konsep boarding school perlu dijadikan solusi untuk mengatasi persoalan di atas. Dengan boarding school pembinaan terhadap anak didik bisa lebih efektif karena ia berada dalam pengawasan sekolah sepanjang waktu. Lewat konsep boarding school lembaga pendidikan bisa mengembangkan program unggulan sebagai langkah untuk meningkatkan mutu lulusan, seperti kemampuan berbahasa asing, tahfiøh al-Qur'an, berwirausaha, berternak, bertani, berkebun,dan lain-lain. Dengan konsep boarding school para siswa tidak hanya dididik menjadi orang baik, tetapi juga dilatih menjadi orang terampil. Dengan keterampilan yang dimilikinya para lulusan lembaga pendidikan Islam diharapkan mampu mendapatkan kehidupan yang layak.

Kalau lembaga pendidikan Islam mampu melahirkan lulusan yang unggul maka lembaga ini akan menjadi impian bagi banyak orang sebagai tempat belajar. Masyarakat akan menaruh kepercayaan besar terhadapnya. Oleh sebab itu konsep boarding school merupakan salah satu cara untuk melahirkan lulusan yang bermutu, serta salah satu langkah untuk menarik minat masyarakat.

9. Pemerataan pendidikan Islam perlu dilakukan sampai ke semua lini kehidupan. Untuk itu para pegiat atau praktisi pendidikan Islam perlu memberdayakan segala potensi dimiliki baik Sumber Daya Manusia (SDM) maupun Sumber Daya Alam (SDA). Pemerataan pendidikan Islam tidak hanya bisa dilakukan dengan membangun lembaga pendidikan baru, tetapi juga dengan membuat kelompok-kelompok pengajian seperti majelis ta'lim, lewat media massa (baik cetak maupun online), serta lewat program literasi, seperti membuat perpustakaan mesjid/mushalla. Upaya-upaya tersebut didesain sedemikian rupa sehingga ia memiliki daya tarik dan berlangsung secara efektif.

10.Pengembangan dan peningkatan kualitas pendidikan Islam perlu dilakukan dengan merangkul dan memberdayakan masyarakat. Sebab lembaga pendidikan tidak bisa berjalan tanpa dukungan dari mereka. Untuk itu 
lembaga pendidikan Islam perlu menjalin silaturahmi dengan masyarakat, membina mereka secara berkala, serta melibatkan mereka dalam upaya pengembangan dan peningkatan mutu lembaga, supaya mereka punya rasa memiliki terhadap lembaga tersebut. Kalau masyarakat sudah punya rasa memiliki terhadap lembaga pendidikan tentu mereka akan mudah diajak untuk ambil bagian dalam menjalankan program lembaga, terutama dalam mengelola dan meningkatkan mutu pendidikan. Setelah menyampaikan uraian tentang eksistensi pendidikan Islam dalam bingkai regulasi pendidikan nasional di Indonesia,

\section{Penutup}

Dari uraian di atas, bahwa: Pendidikan Islam di Indonesia bergerak secara dinamis seiring terjadinya dinamika sosial dan politik di Indonesia. Lahirnya Undang- Undang Nomor 20 Tahun 2003 dan Undang - Undang Nomor 18 Tahun 2019 memberikan angin segar bagi pendidikan Islam di Indonesia karena kedua Undang-Undang tersebut memperkuat kedudukan pendidikan Islam dan memberikan ruang gerak yang luasuntuk maju dan berkembang. Dalam pelaksanaan pendidikan Islam di tengah masyarakat Indonesia masih ditemukan beberapa kendala yang dapat mereduksi efektifitas pencapaian tujuannya.

\section{Bibliografy}

Arifin, H.M. Pendidikan Islam dalam Arus Dinamika Masyarakat, (Jakarta: Golden Terayon Press, 1991)

Arifin, H.M. Kapita Selekta Pendidikan Islam dan Umum, (Jakarta: Bumi Aksara, 1991)

Chairusdi, Sejarah Perjuangan dan Kiprah PERTI dalam Dunia Pendidikan Islam di Minangkabau, ( Padang: IAIN “IB" Press, 1999)

Departemen Agama RI, Panduan Kurikulum Madrasah Aliyah1994, (Jakarta: Depag RI, 1994)

Azra, Azyumardi, Pendidikan Islam Tradisi dan Modernisasi Menuju Milenium Baru, (Jakarta: Logos Wacana Ilmu, 1999)

Daulay, Haidar Putra, Pendidikan Islam dalam Sistem Pendidikan Nasional di Indonesia, (Jakarta: Prenada Media, 2004)

Daradjat, Zakiah, Ilmu Pendidikan Islam, (Jakarta: Bumi Aksara, 2000) 
Hanipudin, Sarno, Pendidikan Islam di Indonesia dari Masa ke Masa, Matan Journal of Islam and Muslim Society 1, 1 (2019) : 2 - 5

Idi, Abdullah dan Suharto Ito, Revitalisasi Pendidikan Islam, (Yogyakarta: Tiara Wacana, 2006)

Meirison, Meirison. "Kurds, Islam, and Secularism." MADANLA: JURNAL KAJLAN KEISLAMAN 23, no. 1 (July 7, 2019): 47.

Meirison Meirison, Sarmida Hanum, Wisyly Wahab, and Rahma Ghania Alhafiza. "نمط الدعوة في إندونيسيا وتحدياته." AL-'ABQARI: Journal of Islamic Social Sciences and Humanities 0, no. 0 (October 3, 2019). Accessed October 31 , 2019. http://abqarijournal.usim.edu.my/index.php/abqari/article/view/193.

Muhaimin, Nuansa Baru Pendidikan Islam : Mengurai Benang Kusut Dunia Pendidikan, (Jakarta: Raja Grafindo Persada, 2006)

Nizar, Samsul, Sejarah Pendidikan Islam, (Jakarta : Kencana Prenada Media Group, 2009)

Undang-Undang Nomor 2 Tahun 1989 Tentang Sistem Pendidikan Nasional

Undang-Undang Nomor 20 Tahun 2003 tentang Sistem Pendidikan Nasional

Undang-Undang Nomor 18 Tahun 2019 tentang Pesantren

Quthb, Muhammad, Sistem Pendidikan Islam, Alih Babasa Salman Harun, (Bandung: Al-Ma'arif, 1984 )

Suroyo, Berbagai Persoalan Pendidikan; Pendidikan Nasional dan Pendidikan Islam di Indonesia, Jurnal Pendidikan Islam, Kajian tentang Konsep Pendidikan Islam, Problem dan Prospeknya, Volume 1 Tahun 1991, Fakultas Tarbiyah IAIN, Yogyakarta

Ramayulis, Ilmu Pendidikan Islam, (Jakarta: Kalam Mulia, 2013)

Ramayulis, Sejarah Pendidikan Islam, (Jakarta: Kalam Mulia, 2012)

Zuhairini, Sejarah Pendidikan Islam, (Jakarta: Bumi Aksara, 1997) 